\title{
Is Facet Tropism an Acquired Status or is It Related with Age? MRI Study
}

\author{
Faset Tropizm Edinsel midir, Yaş ile Bir ilişkisi Var mıdır? MRG Çalışması \\ ๑ Tuba Selçuk Can, ๑ Sevim Özdemir*, ๑ Behice Kaniye Yılmaz* \\ Istanbul Gelişim University, Vocational School of Health Services, Istanbul, Turkey \\ *Haseki Training and Research Hospital, Clinic of Radiology, istanbul, Turkey
}

\section{Abstract}

Aim: We aimed to reveal the facet joint orientation and tropism and their relationship with age in patients without degenerative spine disease in lumbar magnetic resonance imaging (MRI) examinations.

Methods: After obtaining approval from the ethics committee, patients who were referred to our clinic for a lumbar MRI between June 2018 and December 2018 for low back pain were reviewed retrospectively. When the line that is tangent to the posterior of the intervertebral disc was considered as reference, tropism was considered when the difference between the anteromedial and posterolateral line of superior articular facet on the right and left sides, and the angles between this reference lines were $>10^{\circ}$.

Results: The study included 113 patients aged 15-55 years (30.87 \pm 9.23$)$ who underwent lumbar MRI for various reasons and with reports of normal lumbar MRI examination. Sixty-sevenpoint three percent $(n=76)$ of the patients were female and $32.7 \%(n=37)$ were male.

Conclusion: According to the results of our study, facet joint orientation has increased angular values in the craniocaudal direction regardless of age, and it shows more coronal orientation compared to other levels, especially at the L4-5 and L5-S1 levels. We may conclude that facet tropism is independent of age and is an acquired condition which degenerative processes may contribute to.

Keywords: Facet tropism, facet orientation, age
Amaç: Çalışmamızda lomber manyetik rezonans görüntüleme (MRG) tetkikleri sonucunda dejeneratif omurga hastalığı bulunmayan kişilerde faset eklem oryantasyon ve tropizmleri ile bunların yaş ile ilişkilerini ortaya koymayı amaçladık.

Yöntemler: Etik kurul onayı alındıktan sonra Haziran 2018-Aralık 2018 tarihleri arasında kliniğimize lomber MRG tetkiki için refere edilen hastalar retrospektif olarak tarandı. Intervertebral disk posterioruna teğet geçen çizgi referans olarak kabul edildiğinde sağ ve sol tarafta superior artiküler fasetin anteromedial ve posterolateralinden geçen çizgi ile bu referans çizgi arasında kalan açılar arasındaki fark $>10^{\circ}$ olduğunda tropizm olarak değerlendirildi.

Bulgular: Çalışmaya lomber MRG çektiren ve raporları "normal sınırlarda lomber MRG incelemesi" şeklinde olan 15-55 yaş arası $(30,87 \pm 9,23) 113$ kişi dahil edildi. Olguların \%67,3'ü $(n=76)$ kadın ve \%32,7'si ( $n=37)$ erkekti. Çalışmaya çeşitli sebeplerle lomber MRG çektiren ve raporları "normal sınırlarda lomber MRG incelemesi" şeklinde olan 15-55 yaş arası $(30,87 \pm 9,23) 113$ kişi dahil edildi.

Sonuç: Çalışmamızın sonuçlarına göre faset eklem oryantasyonu yaştan bağımsız şekilde kraniokaudal yönde artan açı değerlerine sahip olup özellikle L4-5 ve L5-S1 seviyelerinde diğer seviyelere göre daha koronal oryantasyon göstermektedir. Faset tropizmi yaştan bağımsız olup dejeneratif süreçlerin de katkısı olabilecek edinsel gelişen bir durumdur.

Anahtar Sözcükler: Faset eklem tropizmi, faset eklem oryantasyonu, yaş
Address for Correspondence/Yazışma Adresi: Sevim Özdemir, Haseki Training and Research Hospital, Clinic of Radiology, İstanbul, Turkey E-mail: sevimozdemir76@yahoo.com ORCID: orcid.org/0000-0003-4270-6370 Received/Geliş Tarihi: 16 May 2019 Accepted/Kabul Tarihi: 05 July 2019
${ }^{\circ}$ Copyright 2019 by The Medical Bulletin of istanbul Haseki Training and Research Hospital The Medical Bulletin of Haseki published by Galenos Yayınevi. ${ }^{\circledR}$ Telif Hakkı 2019 istanbul Haseki Eğitim ve Araştırma Hastanesi Haseki Tıp Bülteni, Galenos Yayınevi tarafından yayınlanmıştır. 


\section{Introduction}

Intervertebral discs between the vertebrae corpus anteriorly and the facet joints (FJs) between the superior and inferior articular processes posteriorly play a role in the stabilization of the vertebrae. FJs carry approximately $33 \%$ of the dynamic load of the vertebrae by preventing excessive rotation, flexion or translation (1). Several studies have shown that degenerative spondylolisthesis was associated with more sagittal orientation rather than the coronal orientation of the FJs, especially at the L4-L5 level (2). However, the effect of facet tropism, which is asymmetry in FJs, is not apparent. Similarly, the relationship between degenerative spine disease and FJs has been the subject to various studies. Some studies have shown that asymmetry in FJs was a result of degenerative disc disease, and in contrast, some studies have suggested that asymmetry in FJs contributed to degenerative processes in the spine as a result of disproportionate load distribution (3-6). Based on this situation, which is still a subject of debate, we aimed to reveal the FJ orientation and tropism and their relationship with age in patients without degenerative spine disease in lumbar magnetic resonance imaging (MRI) examinations.

\section{Methods}

After obtaining approval from the ethics committee, the reports and clinical information of patients referred to our clinic for a lumbar MRI examination between June 2018 and December 2018 for low back pain were reviewed retrospectively. The exclusion criteria were history of surgery, trauma, spinal inflammation-infectious diseases, spinal malignancy and congenital vertebral anomalies. A total of 113 patients with images which are free of degenerative lumbar disease were included in the study.

All lumbar MRI images were obtained according to the standard lumbar MRI protocol (Axial T2-weighted fast spin echo; $T R=3800, T E=100$, Sagittal $T 2$-weighted fast spin echo; $T R=2500, T E=100$, Sagittal T1-weighted spin echo $T R=500, T E=10$ ) with a Philips Achieva MRI device (Philips Healthcare, Best, The Netherlands). The images were evaluated on the workstation (INFINITT PACS, Infinitt Healthcare, South Korea).

When the line that was tangent to the posterior of the intervertebral disc was considered reference, tropism was considered when the difference between the anteromedial and posterolateral line of superior articular facet on the right and left sides, and the angles between this reference lines were $>10^{\circ}$ (Figure 1).

In the evaluation of the facet orientation, the line passing through the center of the intervertebral disc and spinous process basis were accepted as a reference.
The mean value of the angle between the line passing through the anteromedial and posterolateral corners of the superior articular facets and the reference line for the right and left sides were determined as the facet orientation angle for the respective level. When the orientation angle was $>45^{\circ}$, it was considered to be coronal, and when the orientation angle was $\leq 45^{\circ}$, it was considered to be sagittal (Figure 2). All measurements were performed independently by two radiologists with six and four years of experience with spinal imaging, respectively. Then, the average of two measurements for each level was taken, and this average value was used in the statistical analysis.

\section{Statistical Analysis}

Statistical analyses of the data were done by SPSS (Statistical Package for the Social Sciences) version 15.0. Continuous variables were expressed as mean, standard deviation, median, minimum, maximum and categorical variables as frequency and percentage. For the categorical variables chi-square and Fisher's exact tests were used; for continuous variables, the Mann-Whitney $U$ test was used for comparison of two groups and the Friedman test was used for comparison of five levels. The results were evaluated with a 95\% confidence interval and a significance level of $p<0.05\left({ }^{*} p<0.05,{ }^{* *} p<0.01\right.$, $* * * p<0.001)$.

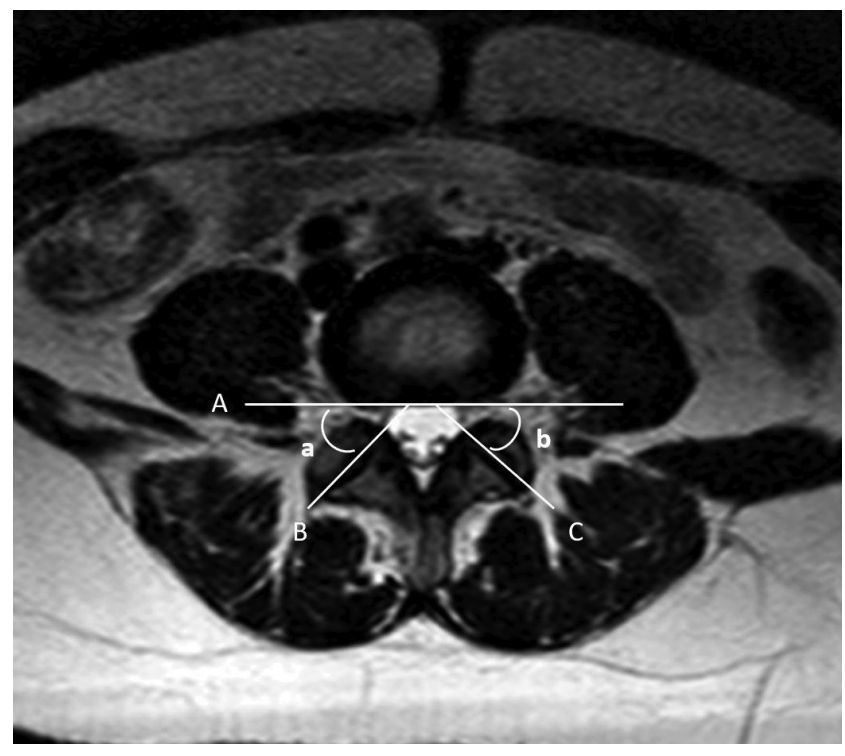

Figure 1. Evaluation of facet tropism. In T2-weighted axial MR images line " $A$ " is the reference line passing through the posterior border of the intervertebral disc. Lines connecting the anteromedial and posterolateral borders of the superior articular facets to the reference line on both sides; right (line B) and left (line $C$ ). The difference of the facet angles on both sides $(a-b)$ is the facet tropism angle MR: Magnetic resonance 


\section{Results}

The study included 113 patients aged 15-55 years (30.87 \pm 9.23$)$ who underwent lumbar MRI for various reasons and with reports of normal lumbar MRI examination. $67.3 \%(n=76)$ of the patients were female and $32.7 \%(n=37)$ were male.

The presence and direction of facet tropism evaluated in the cases are shown in Table 1.

There was no statistically significant difference in facet tropism at lower lumbar vertebral levels between genders.

There was no statistically significant difference in age between patients with and without tropism $(p>0.05)$ (Table 2).

The facet orientation angle was found to be significantly increased from L1-L2 to L5-S1, from top to bottom $(p<0.001)$ (Table 3$)$.

The evaluation of facet orientations by levels is shown in Table 4.

\section{Discussion}

Facet joints are synovial joints that play an essential role in the segmental balance of the spine. Recently, the relationship between abnormalities in FJs and degenerative spine diseases has been frequently investigated. Kalichman et al. (6) concluded that the sagittal orientation of the FJs was associated with degenerative spondylolisthesis due to increased shear force effect. Similarly, facet tropism is

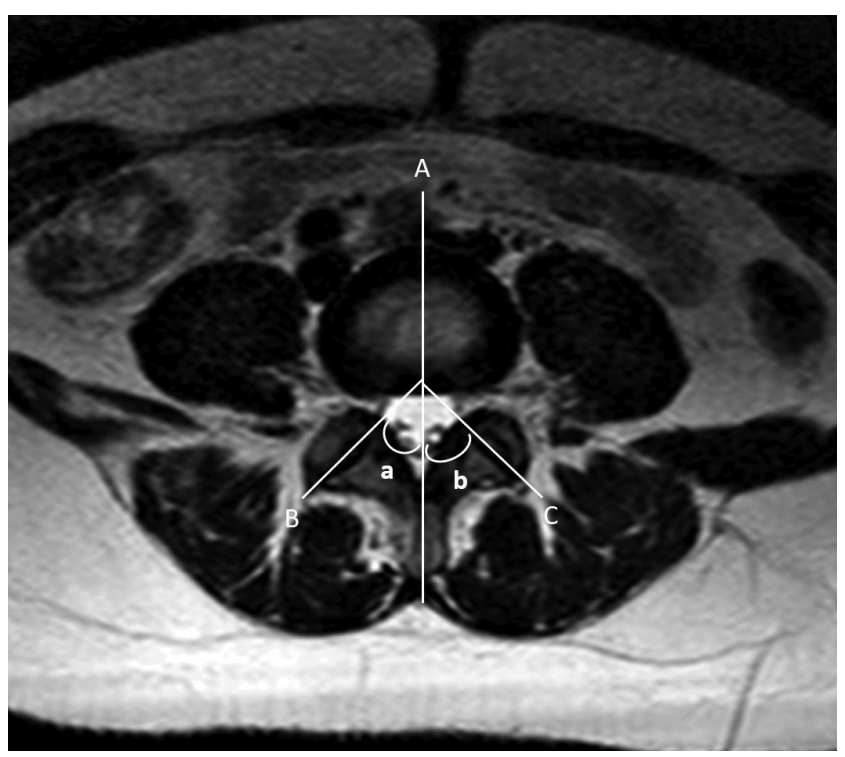

Figure 2. Evaluation of the facet orientation. In T2-weighted MR images line " $A$ " is the reference line connecting the center of the intervertebral disc and the base of the spinous process. Facet orientation angle is the sum of the angles $(a+b)$ between this reference line and the line connecting the anteromedial and posterolateral corners of the superior articular facets (line B and line C)

MR: Magnetic resonance also associated with degenerative spondylolisthesis due to abnormal unbalanced loading on the spine (7-9). Lumbar disc herniation, another degenerative spinal disease, and morphological abnormalities in FJs are another concern which interests authors. When intervertebral disc and FJs are considered a triple joint complex (10), it has been demonstrated by several studies that an abnormality that may occur in one component of this triple complex may affect others and cause abnormal loading (11). However, in all these studies, it is unclear whether FJ orientation or tropism is a primary variational abnormality or a condition developing secondary to the degenerative process. It has been shown that degenerative spine disease was observed in the presence of FJ tropism and that increased sagittal orientation in the FJ was associated with degenerative spondylolisthesis, especially at lower lumbar levels $(9,12)$. However, the causal relationship is ambiguous.

In a study by Wang et al. (12), in the control group consisting of 30 people with a mean age of 40.56 who did not have lumbar pathology, the FJs showed a more horizontal orientation towards L5-S1 level as in our study. In their CT study investigating FJ arthritis, Jentzsch et al. (13) found that FJ arthritis increased with age, and there was no gender difference. They also found that more coronal FJ orientation at the L2-3 level was associated with degeneration. They did not find a relationship with

\begin{tabular}{|c|c|c|}
\hline & $\mathbf{n}$ & $\%$ \\
\hline \multicolumn{3}{|c|}{ L1-L2 tropism } \\
\hline$(-)$ & 88 & 77.9 \\
\hline Right (+) & 18 & 15.9 \\
\hline Left $(+)$ & 7 & 6.2 \\
\hline \multicolumn{3}{|c|}{ L2-L3 tropism } \\
\hline$(-)$ & 84 & 74.3 \\
\hline Right (+) & 21 & 18.6 \\
\hline Left $(+)$ & 8 & 7.1 \\
\hline \multicolumn{3}{|c|}{ L3-L4 tropism } \\
\hline$(-)$ & 83 & 73.5 \\
\hline Right (+) & 24 & 21.2 \\
\hline Left $(+)$ & 6 & 5.3 \\
\hline \multicolumn{3}{|c|}{ L4-L5 tropism } \\
\hline$(-)$ & 84 & 74.3 \\
\hline Right (+) & 26 & 23.0 \\
\hline Left $(+)$ & 3 & 2.7 \\
\hline \multicolumn{3}{|c|}{ L5-S1 tropism } \\
\hline$(-)$ & 86 & 76.1 \\
\hline Right (+) & 15 & 13.3 \\
\hline Left $(+)$ & 12 & 10.6 \\
\hline
\end{tabular}


Table 2. Relationship of facet tropism and age

\begin{tabular}{|l|l|l|l|l|l|}
\hline & \multicolumn{2}{l|}{ Tropism (-) } & Tropism (+) & \multirow{2}{*}{} \\
\cline { 2 - 6 } & $\mathbf{n}$ & \% & $\mathbf{n}$ & \% & \\
\hline L1-L2 & 30.62 & 9.05 & 31.72 & 10.00 & 0.520 \\
\hline L2-L3 & 31.38 & 9.31 & 29.38 & 9.01 & 0.335 \\
\hline L3-L4 & 31.06 & 9.12 & 30.33 & 9.68 & 0.787 \\
\hline L4-L5 & 31.44 & 9.33 & 29.21 & 8.88 & 0.214 \\
\hline L5-S1 & 30.97 & 9.13 & 30.56 & 9.72 & 0.793 \\
\hline
\end{tabular}

Table 3. Facet orientation angles by level

\begin{tabular}{|l|l|l|l|l|l|l|}
\hline & Mean & SD & Median & Min & Max & p \\
\hline L1-L2 & 27.39 & 8.70 & 27.00 & 12.50 & 50.00 & $\mathbf{0 . 0 0 0 1 * * *}$ \\
\hline L2-L3 & 29.65 & 8.77 & 29.50 & 8.00 & 48.50 \\
\hline L3-L4 & 35.58 & 9.63 & 35.50 & 10.50 & 60.00 \\
\hline L4-L5 & 42.95 & 9.45 & 44.00 & 10.5 & 65.5 \\
\hline L5-S1 & 48.23 & 8.61 & 47.00 & 25.50 & 67.50 \\
\hline
\end{tabular}

SD: Standard deviation, Min: Minimum, Max: Maximum $\star * * p<0.001$

\section{Table 4. Facet orientations by levels}

\begin{tabular}{|c|c|c|}
\hline & $\mathbf{n}$ & $\%$ \\
\hline \multicolumn{3}{|l|}{ L1-L2 } \\
\hline Sagittal & 111 & 98.2 \\
\hline Horizontal & 2 & 1.8 \\
\hline
\end{tabular}

\begin{tabular}{|l|l|l|}
\hline Sagittal & 109 & 96.5 \\
\hline Horizontal & 4 & 3.5 \\
\hline L3-L4 &
\end{tabular}

\begin{tabular}{|l|l|l|}
\hline Sagittal & 93 & 82.3 \\
\hline Horizontal & 20 & 17.7 \\
\hline L4-L5 & 63 & 55.8 \\
\hline Sagittal & 50 & 44.2 \\
\hline Horizontal & \multicolumn{2}{l|}{} \\
\hline L5-S1 & 45 & 39.8 \\
\hline Sagittal & 68 & 60.2 \\
\hline Horizontal & \multicolumn{2}{|l}{} \\
\hline n: Number & \multicolumn{5}{|l|}{} \\
\hline
\end{tabular}

FJ asymmetry. In our study, although the orientation angles were found to be smaller at each level, the coronal orientation in the lower levels did not vary. In our study, the facet tropism in males was more common than in females, although the difference was not statistically significant. This may be due to men working in jobs requiring more physical power. If we consider that facet tropism is acquired, facet tropism would be the result of FJ degeneration or degenerative disc disease that may lead to an asymmetrical load over these structures altering their dynamic balance. But our study population was free of degenerative disc and FJ disease. This explains the fact that there was not such a triggering effect that may lead to facet tropism and as a consequence of that, there was not enough time interval for the development of an acquired pathology like facet tropism in our study. In addition, the fact that there was no correlation between the presence of facet tropism and age in our study also supports the hypothesis that this condition may be an acquired condition.

\section{Study Limitations}

The limitation of our study was that it did not represent an asymptomatic population. In the study group, however, lumbar MRI examinations were within the normal limits in terms of degenerative disease, excluding the fact that the results obtained in our study for FJs were secondary to a degenerative process.

\section{Conclusion}

As a result, according to the results of our study, FJ orientation has increased angular values in the craniocaudal direction, regardless of age, and it shows more coronal orientation compared to other levels, especially at L4-5 and L5-S1 levels. Facet tropism is also independent of age and is an acquired condition that degenerative processes may contribute to its pathogenesis.

\section{Authorship Contributions}

Concept: T.S.C. Design: T.S.C. Data Collection or Processing: T.S.C., S.Ö., B.K.Y. Analysis or Interpretation: 
T.S.C., S.Ö., B.K.Y. Literature Search: T.S.C., S.Ö., B.K.Y. Writing: T.S.C.

Conflict of Interest: No conflict of interest was declared by the authors.

Financial Disclosure: The authors declared that this study received no financial support.

\section{References}

1. Yang $\mathrm{KH}$, King Al. Mechanism of facet load transmission as a hypothesis for low-back pain. Spine (Phila Pa 1976) 1984;9:557-65.

2. Samartzis D, Cheung JP, Rajasekaran $S$, et al. Critical Values of Facet Joint Angulation and Tropism in the Development of Lumbar Degenerative Spondylolisthesis: An International, Large-Scale Multicenter Study by the AOSpine Asia Pacific Research Collaboration Consortium. Global Spine J 2016;6:414-21.

3. Kim HJ, Chun HJ, Lee HM, et al. The biomechanical influence of the facet joint orientation and the facet tropism in the lumbar spine. Spine J 2013;13:1301-8.

4. Chadha M, Sharma G, Arora SS, Kochar V. Association of facet tropism with lumbar disc herniation. Eur Spine J 2013;22:1045-52.

5. Do DH, Taghavi CE, Fong W, Kong MH, Morishita Y, Wang JC. The relationship between degree of facet tropism and amount of dynamic disc bulge in lumbar spine of patients symptomatic for low back pain. Eur Spine J 2011;20:71-8.
6. Kalichman L, Suri P, Guermazi A, Li L, Hunter DJ. Facet orientation and tropism: associations with facet joint osteoarthritis and degeneratives. Spine (Phila Pa 1976) 2009;34:E579-85.

7. Leonid K, David JH. Degenerative lumbar spondylolisthesis: anatomy, biomechanics and risk factors. J Back Musculoskelet Rehabil 2008;21:1-12.

8. Dai LY. Orientation and tropism of lumbar facet joints in degenerative spondylolisthesis. Int Orthop 2001;25:40-2.

9. Devine JG, Schenk-Kisser JM, Skelly AC. Risk factors for degenerative spondylolisthesis: a systematic review. Evid Based Spine Care J 2012;3:25-34.

10. Iorio JA, Jakoi AM, Singla A. Biomechanics of Degenerative Spinal Disorders. Asian Spine J 2016;10:377-84.

11. Sengupta DK, Fan $H$. The basis of mechanical instability in degenerative disc disease: a cadaveric study of abnormal motion versus load distribution. Spine (Phila Pa 1976) 2014;39:1032-43.

12. Wang H, Zhang Z, Zhou Y. Irregular Alteration of Facet Orientation in Lumbar Segments: Possible Role in Pathology of Lumbar Disc Herniation in Adolescents. World Neurosurg 2016;86:321-7.

13. Jentzsch T, Geiger J, Zimmermann SM, Slankamenac K, Nguyen-Kim TD, Werner CM. Lumbar facet joint arthritis is associated with more coronal orientation of the facet joints at the upper lumbar spine. Radiol Res Pract 2013;2013:693971. 